\title{
L-Proline Transport by Isolated Renal Tubules from Newborn and Adult Rats
}

\author{
SHING MEI HWANG, MERCEDES A. SERABIAN, KARL. S. ROTH, AND STANTON SEGAL ${ }^{(26)}$ \\ Departments of Pediatrics and Medicine, University of Pennyslvania School of Medicine and Division of Biochemical \\ Development and Molecular Diseases, Children's Hospital of Philadelphia, Philadelphia, Pennsylvania, USA
}

\begin{abstract}
Summary
Proline uptake and metabolism has been examined in newborn Sprague-Dawley rat kidney and compared to that in adult animals. $I^{14} \mathrm{Cl}$-Proline uptake by renal tubule fragments from newborn rats occurs at the same initial rate as in adult tubules, but at physiologic concentrations achieves significantly higher intracellular levels after $15 \mathrm{~min}$ of incubation. Considerable metabolism of the proline taken up was observed in tissue of both ages. Analysis of acid soluble and insoluble tubule fractions from newborn and adults indicates similar degrees of proline incorporation into protein and oxidation to $\mathrm{CO}_{2}$ relative to the amount of radioactivity taken up. A major difference exists, however, with respect to the labeled components of the acid extract: adult tubules convert $\left[{ }^{14} \mathrm{Cl}\right.$-proline to metabolites at a rate twice that of newborn. Analysis of concentration-dependent uptake data reveals two distinct entry systems for proline in both isolated newborn and adult tubules. No difference in the Km or Vmax was found between the young and mature tubules.
\end{abstract}

\section{Speculation}

These data indicate that the higher proline excretion by newborn animals is not the consequence of impaired uptake or the absence of any component of the process mediating proline influx, but must be related to other factors involved in the transcellular movement of the amino acid from the tubule lumen to the peritubular capillary.

The physiologic hyperaminoaciduria observed in the young of several species $(6,25)$ has stimulated a number of investigations to determine the underlying developmental alterations in renal tubule transport mechanisms. The impetus for such studies has been not only to increase understanding of normal transport processes but also to gain insight into aberrant transport as observed in inherited disorders such as iminoglycinuria. Indeed, many in vitro experiments have focused on the differences in uptake of glycine and proline by various tubule cell preparations of newborn and adult rats. As a result of early studies with renal cortical slices two divergent points of view emerged. Scriver's group $(3,4,5)$ had shown slow uptake in very young tissue and the absence of a high affinity transport system for both glycine and proline which appeared during tubule development. On the other hand, in our own laboratory, employing both cortical slices and renal tubule fragments, we consistently observed the presence of two distinct transport systems for glycine in the newborn as in the adult and stressed other possible reasons for the aminoaciduria than diminished glycine uptake $(15,18,24)$.

Although these fundamental discrepancies have been attributed to methodologic or rat strain differences, an extensive analysis of these factors has shown the presence of two distinct glycine transport systems in the newborn rat. In resolving the debate over development of glycine transport in rat kidney, we espoused the advantages of using separated tubule fragments rather than cor- tical slices to assess transport kinetics. The tubule fragment preparation eliminates difficulties in controlling thickness of slices and the architectural impediments to substrate movement. In this paper we have applied this methodology to the further study of the developmental aspects of proline transport in Sprague-Dawley rat kidney and demonstrate the presence of two systems for proline entry which are similar in newborn and adult tubules.

\section{MATERIALS AND METHODS}

$\mathrm{L}-\left[{ }^{14} \mathrm{C}\right]-(\mathrm{U})$-Proline $(283 \mathrm{mCi} / \mathrm{mmole})$ was purchased from $\mathrm{New}$ England Nuclear Corporation (Boston, MA) and unlabeled proline from Sigma (St. Louis, MO). Sprague-Dawley females, 15 days pregnant, and adult male rats were obtained from Charles River Breeding Laboratories (Wilmington, MA). Pregnant females were housed separately until parturition. The pups and 11-15-wk old adult rats were killed by decapitation. The kidneys were removed and placed in ice cold Krebs-Ringer bicarbonate buffer (KRB), pH 7.4. Newborn cortical slices were cut with a sharp blade in a freehand manner and adult cortical slices were made with a Stadie-Riggs microtome. The preparative method for tubule fragments using collagenase treatment has been reported previously $(7,10,19,20)$.

Comparative uptake studies were performed in newborn (up to $48 \mathrm{~h}$ of age) and adult tubule preparations simultaneously in Burg and Orloff flasks with continuous bubbling of a $95 \% \mathrm{O}_{2}-5 \% \mathrm{CO}_{2}$ mixture as described previously (7). The study was initiated by addition of $\left[\mathrm{C}^{14}\right]$-proline and terminated by removing samples into tared tubes which were placed in ice water. The tubes were then centrifuged at $2^{\circ} \mathrm{C}$ for $10 \mathrm{~min}$ at $33,000 \times g$ and the supernatants removed for counting. The pellet surface and the test tube wall were washed once with ice cold buffer and dried by suction. After weighing the tube, the pellets were resuspended in $1 \mathrm{ml}$ of distilled water and the tubes were placed in a boiling water bath for $3 \mathrm{~min}$ after centrifugation. Two-tenths $\mathrm{ml}$ aliquots of the water extracts of the pellets and the corresponding incubation supernatants were added to $10 \mathrm{ml}$ of a scintillation cocktail $(2.8 \mathrm{ml}$ absolute alcohol $+7 \mathrm{ml}$ OCS; Amersham Corp., Arlington Heights, IL) and counted in a Packard liquid scintillation counter.

Tissue water, expressed as the $\%$ of the total tissue weight was determined by overnight desiccation of the tissues. Extracellular (trapped medium) fluid space estimation was determined by the method of Rosenberg et al. (17), using inulin- $\left[{ }^{14} \mathrm{C}\right]$-carboxylic acid (Amersham Corp.). Uptake of proline was expressed as a distribution ratio calculated as previously described by Rosenberg $e t$ al. (16) and defined as the ratio of $\mathrm{cpm} / \mu \mathrm{l}$ intracellular fluid to $\mathrm{cpm} / \mu \mathrm{l}$ medium.

In experiments to determine proline incorporation into protein and oxidation to $\mathrm{CO}_{2}$, the incubation was performed in sealed flasks fitted with or without center wells in a $37^{\circ} \mathrm{C}$ shaker bath. The tubules were incubated with proline in $2 \mathrm{ml} \mathrm{KRB}, \mathrm{pH} \mathrm{7.4}$, saturated with $95 \% \mathrm{O}_{2}-5 \% \mathrm{CO}_{2}$. At various incubation times, the tubule suspensions from the flasks without center wells were pipetted into tared tubes for uptake studies. The tubes were 
centrifuged and wet tissue weights obtained. The pellets were resuspended in $0.8 \mathrm{ml}$ of distilled water and then $0.2 \mathrm{ml}$ of $50 \%$ trichloracetic acid (TCA) was added to the water suspension. After cooling in ice for $10 \mathrm{~min}$, the tubes were centrifuged to obtain TCA soluble and insoluble fractions. TCA insoluble material was washed once with $10 \%$ cold TCA. The final pellets were dissolved in $0.5 \mathrm{ml}$ of Soluene 100 (Packard) and counted in $10 \mathrm{ml}$ of OCS. The TCA extracts were counted in the same scintillation cocktail. Accumulated radioactivity in TCA soluble and TCA insoluble fractions was expressed as a distribution ratio equivalence. The averaged wet weights obtained from uptake flasks were used for the determination of $\mathrm{CO}_{2}$ evolution from the flasks with the center wells. In the latter experiments, injection of $0.4 \mathrm{ml}$ of $50 \%$ TCA ended the incubation. The liberated $\left[{ }^{14} \mathrm{CO}_{2}\right]$ was trapped in the center well containing $0.4 \mathrm{ml}$ of $1 \mathrm{M}$ Hyamine $10-\mathrm{X}$ (Packard) during an additional $45 \mathrm{~min}$ of shaking in the bath. The center wells were counted in $10 \mathrm{ml}$ of OCS. The $\mathrm{CO}_{2}$ evolution is expressed as a distribution ratio by assuming $\mathrm{CO}_{2}$ radioactivity remained inside the tubule cells.

Tubule intracellular proline content was examined by descending paper chromatography. Aliquots from the TCA soluble fraction were applied to Whatman $3 \mathrm{MM}$ cellulose which was developed overnight in butanol/acetic acid $/ \mathrm{H}_{2} \mathrm{O}(24: 6: 10, \mathrm{v} / \mathrm{v} / \mathrm{v})$. Onehalf- or $1.0-\mathrm{cm}$ segments of the papers were cut, added to scintillation counting vials and wetted with $2 \mathrm{ml}$ OCS. Standards of proline and glutamate were also chromatographed and the amount of radioactivity in the extracts corresponding to the standards were calculated as \% of the radioactivity applied.

Concentration dependence experiments were analyzed by Hofstee plots drawn by the least squares method and with the aid of a Monroe model 1775 programmable calculator to obtain the parameters of the equation (1):

$$
\mathrm{V}=\frac{\mathrm{Vmax}_{1} \mathrm{~S}}{\mathrm{Km} \mathrm{m}_{1}+\mathrm{S}}+\frac{\mathrm{Vmax}_{2} \mathrm{~S}}{\mathrm{Km}_{2}+\mathrm{S}}
$$

With initial estimates of $\mathrm{Km}$ and Vmax from the Hofstee plot a nonlinear regression analysis was done with an HP-85 computer programmed to calculate these parameters while correcting for a diffusion component.

Urine was collected by bladder puncture from newborn rats within $48 \mathrm{~h}$ of birth. Urinary proline excretion was measured by placing a single 4- and 14-wk-old and three 3-wk-old animals in metabolic cages with access to water (Table 1). After fasting overnight, urine was collected for $24 \mathrm{~h}$ avoiding contamination with stool. Urinary creatinine was determined using a modification of the Jaffe reaction (8). Urine was deproteinized by adding one part of $30 \%$ sulfosalicylic acid to nine parts urine such that the final concentration was $3 \%(\mathrm{w} / \mathrm{v})$, and centrifuging at $33,000 \times g$ at $4^{\circ} \mathrm{C}$ for $20 \mathrm{~min}$. The supernate was removed and proline concentration determined by ion exchange chromatography using

Table 1. Renal cortical tissue proline levels and urinary excretion of proline

\begin{tabular}{llcl}
\hline Age & $\begin{array}{c}\text { Urinary proline } \\
(\mu \text { mole } / \mathrm{mg} \text { creati- } \\
\text { nine })\end{array}$ & $\begin{array}{c}\text { Tissue concentration } \\
(\mu \text { mole } / \mathrm{g})\end{array}$ & \multicolumn{1}{c}{$\begin{array}{c}\text { Plasma level } \\
(\mu \mathrm{mole} / \mathrm{ml})\end{array}$} \\
\hline $\begin{array}{l}\text { New- } \\
\text { born }\end{array}$ & $6.9^{1}$ & $0.59 \pm 0.06(18)^{2}$ & $0.51^{1}$ \\
$3 \mathrm{wk}$ & $0.54(2)$ & & \\
$4 \mathrm{wk}$ & $0.26 \pm 0.07(4)$ & & \\
$12 \mathrm{wk}$ & & $0.38 \pm 0.02(8)^{3}$ & $0.40(2)$ \\
$14 \mathrm{wk}$ & $0.07 \pm 0.01(4)^{3}$ & & $0.36 \pm 0.03(3)^{4}$ \\
\hline
\end{tabular}

${ }^{1}$ A single pooled urine from newborns up to $48 \mathrm{~h}$ of age obtained by bladder puncture from 30 animals and a pooled blood sample from the neck after decapitation of 20 animals was analyzed.

${ }^{2}$ Mean \pm S.E. for number of determinations in parenthesis.

${ }^{3} P$ value for difference from newborn tissue concentration is $<0.01$ and for urinary proline between $4-14 \mathrm{wk}$ is $<0.05$.

${ }^{4}$ Values from Scharf and Wool (Ref. no. 21). a Beckman Amino Acid Analyzer with a W-2 resin bed employing a lithium citrate buffer system. Urinary excretion was then expressed as nmoles of proline/mg creatinine. Plasma amino acid content was measured in a similar fashion. Cortical tissue concentration of proline was determined as described by Blazer-Yost, et al. (2).

\section{RESULTS}

Urinary excretion of proline with age. In order to demonstrate increased prolinuria in young Sprague-Dawley animals, the urinary excretion of proline with age was measured and shown in Table 1 . The proline excreted by the newborn pups up to $48 \mathrm{~h}$ old was 100 -fold greater than the mature adult. With maturation, the amount of proline excreted per $\mathrm{mg}$ of creatinine progressively declines. The demonstration of prolinuria in the newborn indicates that kidney tubules from these animals are suitable for the search for in vitro transport differences from adult tissue. In addition, Table 1 shows the results of the analysis of proline concentration in newborn and adult renal cortex, the newborn having $60 \%$ higher tissue proline levels than the adult. Plasma levels of proline in the newborn are also slightly higher than in the adult.

Age-dependent uptake of $L$-proline. The uptake of proline by newborn (up to $48 \mathrm{~h}$ of age) and adult renal cortical tubules are shown in Figure 1. At 1 min of incubation with $0.05 \mathrm{mM}$ proline, the amount of radioactivity accumulated by newborn tubules is identical to that of the adult; thereafter, the newborn was consistently higher and continued to take up proline in a linear fashion for $60 \mathrm{~min}$. The adult tubules started to approach steady-state

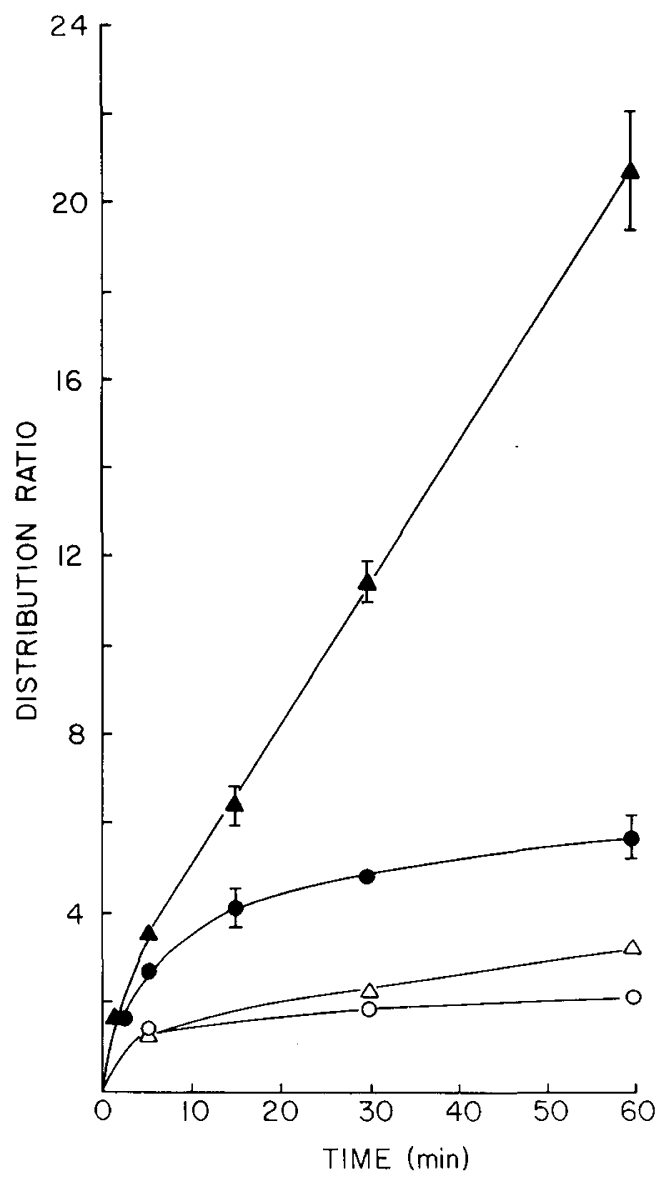

Fig. 1. Time course of proline uptake by rat renal cortical tubules. Tubule suspension, $3-5 \mathrm{mg} / \mathrm{pr} \mathrm{ml}$, was incubated at $37^{\circ} \mathrm{C}$ in Krebs-Ringer bicarbonate buffer, $\mathrm{pH} 7.4$, with $0.1 \mu \mathrm{Ci} / \mathrm{ml}\left[{ }^{14} \mathrm{C}\right]$-proline. The substrate concentrations are $0.05 \mathrm{mM}$ : $(\boldsymbol{\Delta})$ for newborn and $(\boldsymbol{\bullet})$ for adult. At 10 $\mathrm{mM}:(\Delta)$ for newborn and $(O)$ for adult. Each value is the mean \pm S.E. of 6-12 determinations. Where there is no line, the S.E. is within the size of the point. 
after $15 \mathrm{~min}$ of incubation. At $10 \mathrm{mM}$ substrate concentration, the distribution ratio for the newborn tubules was slightly higher only at later time points. The decreased distribution ratios at the higher concentration is indicative of the saturability of the uptake process.

The nature of intracellular radioactivity. When the tubules incubated with $0.05 \mathrm{mM}$ proline were treated with TCA, the radioactivity was present in both TCA soluble and insoluble fractions. The TCA soluble fraction was analyzed for proline content of intracellular fluid. It was found that $63.1 \pm 1.1 \%$ and $60.0 \pm 5.3 \%$ $(n=3)$ of intracellular radioactivity remained as original substrate in newborn tubules but only $35.0 \pm 1.6 \%$ and $32.6 \pm 1.8 \%(n=3)$ in the adult after 5 and $30 \mathrm{~min}$ of incubation respectively. The remaining radioactivity migrated on paper to an area corresponding to glutamate as reported previously $(11,13,14)$. The intracellular proline chemical concentration gradients can be calculated to be 1.6 at $5 \mathrm{~min}$ and 3.2 at $30 \mathrm{~min}$ for newborn tubules; 0.8 at 5 min and 1.2 at 30 min for adults; and indicate an active transport process though differing from the radioactive distribution ratios of Figure 1.

Figure 2 shows the extent of oxidation of $\left[{ }^{14} \mathrm{C}\right]$-proline to $\left[{ }^{14} \mathrm{CO}_{2}\right]$ and the incorporation into cell protein over a $60 \mathrm{~min}$ period by newborn and adult tubule fragments. The young tissue oxidized proline and incorporated it into protein at rates three times that of the adult. These rates appear to reflect the greater uptake of proline by the newborn tissue. This is apparent in Figure 3 where the radioactivity in $\mathrm{CO}_{2}$, protein and soluble in cell fluid is expressed as a \% of the total uptake with $\mathrm{CO}_{2}$ considered as being intracellular. When expressed this way there is little difference between newborn and adult tissue metabolism of proline despite the marked difference in total uptake. The major difference appears to be in the soluble fraction where there is almost twice as much free proline in the newborn than the adult and less is present as proline metabolites (vide supra).

Concentration dependence of uptake. The uptake of proline at 5 min of incubation by tubules was studied over a wide concentration range from $0.01-10 \mathrm{mM}$. Two saturable systems were observed in both newborn and adult tissues. Figure 4 shows a Hofstee plot of the results in which a two-limb curve best fits the data for both newborn and adult tubules with a single line representing both ages. The observed parameters are $\mathrm{Km}_{1}$ of 0.62 $\pm 0.09 \mathrm{mM}, \mathrm{Vmax}_{1} 2.09 \pm 0.36 \mathrm{mmoles} / \mathrm{liter} / 5 \mathrm{~min}$ and $\mathrm{Km}_{2}$ of $21.8 \pm 2.4 \mathrm{mM}, \mathrm{Vmax}_{2}$ of $40.8 \pm 4.3 \mathrm{mmoles} / \mathrm{liter} / 5 \mathrm{~min}$. A nonlinear regression analysis was performed to give the best fit to the observed velocities assuming simultaneous function of two uptake systems with the observed $\mathrm{Km}$ and Vmax values as initial

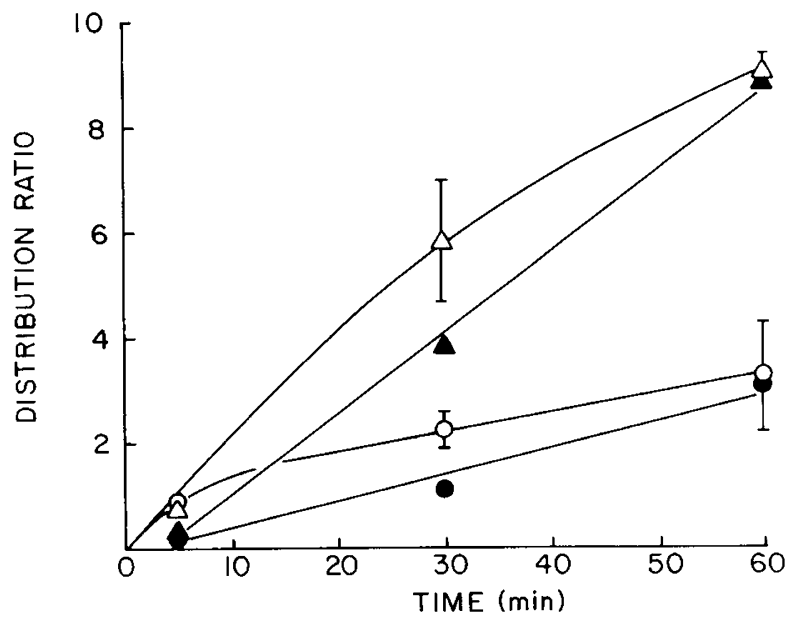

Fig. 2. $\left[{ }^{14} \mathrm{C}\right]$-Proline oxidation to $\mathrm{CO}_{2}$ and incorporation into protein. Tubule suspension, 3-5 mg/pr ml, was incubated with $0.05 \mathrm{mM}\left[{ }^{14} \mathrm{C}\right]-$ proline as described in the text. $\mathrm{CO}_{2}$ evolution is shown for newborn $(\triangle-\triangle)$ and adult $(\mathrm{O}-\mathrm{O})$; protein incorporation for newborn $(\boldsymbol{\Delta}-\boldsymbol{\Lambda})$ and adult $(\longrightarrow)$. Each value is the mean \pm S.E. of 4-6 determinations. Where there is no line, the S.E. is within the size of the point.

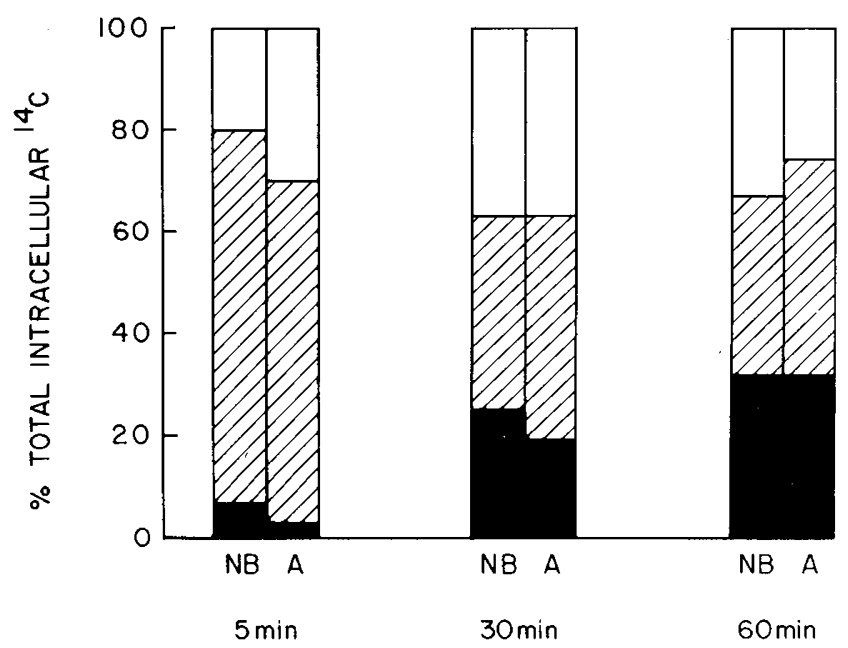

Fig. 3. Fractionation of proline uptake. Tubules were incubated as described in the text in a sealed flask. The radioactivity in $\mathrm{CO}_{2}(\square)$, protein (更), and soluble in the cell fluid $(\square)$ is expressed as a \% of the total uptake with $\mathrm{CO}_{2}$ considered as being intracellular.

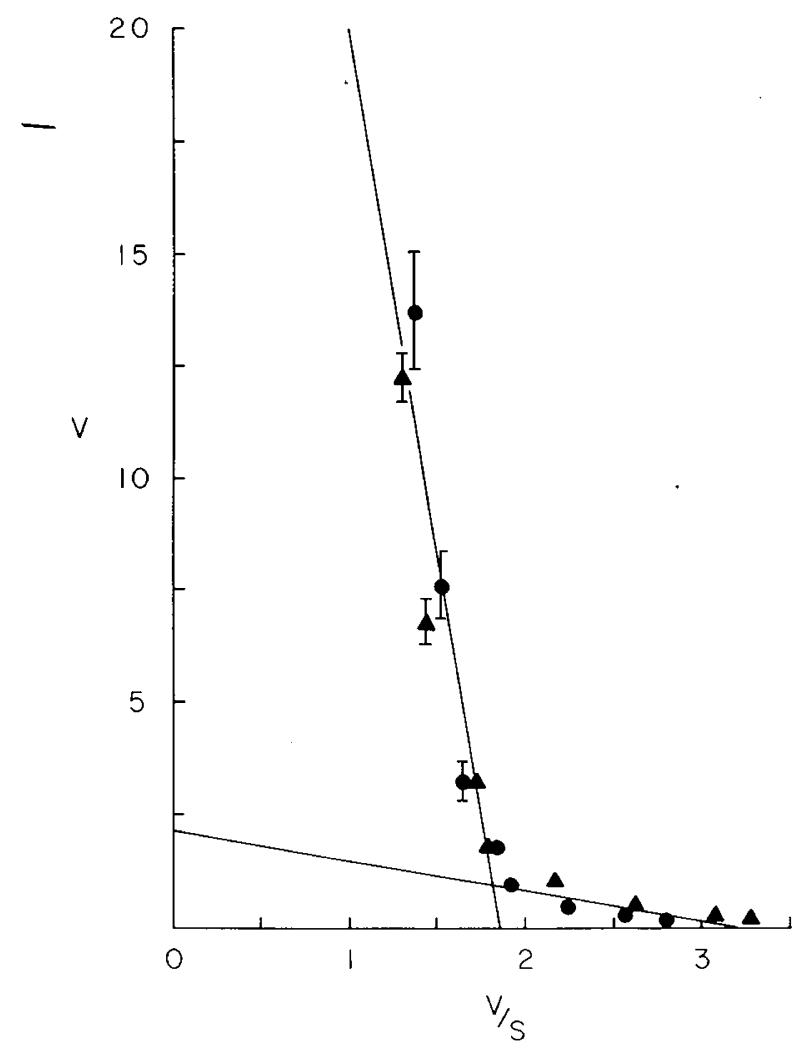

Fig. 4. Hofstee plot of velocity vs velocity over substrate concentration. The tubule suspension, $3-5 \mathrm{mg} / \mathrm{pr} \mathrm{ml}$, was incubated for $5 \mathrm{~min}$ at $37^{\circ} \mathrm{C}$ in Krebs-Ringer bicarbonate buffer, $\mathrm{pH} 7.4$, with $0.1 \mu \mathrm{Ci} / \mathrm{ml}\left[{ }^{14} \mathrm{C}\right]$-proline and sufficient unlabeled proline to give the desired concentrations: $(\boldsymbol{\Lambda}-\boldsymbol{\Lambda})$ newborn and $(-)$ adult. $\mathrm{V}$ is expressed as mmoles/liter/ $5 \mathrm{~min}$ and $\mathrm{S}$ as $\mathrm{mM}$. Each value is the mean \pm S.E. of $6-8$ determinations. Where there is no line, the S.E. is within the size of the point.

estimates $(14,22)$. The calculated values corrected for a diffusion component were $\mathrm{Km}_{1}$ of $0.17 \mathrm{mM}$ and $V \max _{1} 0.32 \mathrm{mmoles} / \mathrm{liter} /$ $5 \mathrm{~min}$. and $\mathrm{Km}_{2}$ of $12.4 \mathrm{mM}$ and $\mathrm{Vmax}_{2} 9.1 \mathrm{mmoles} / \mathrm{liter} / 5 \mathrm{~min}$. The 73-fold difference between the calculated $\mathrm{Km}_{1}$ and $\mathrm{Km}_{2}$ support the presence of multiple transport systems.

In Figure 5, the \% of total uptake via the low and high $\mathrm{Km}$ systems versus the concentration of proline in the media is plotted. At a substrate concentration of $0.05 \mathrm{mM}$, (Fig. 1) the uptake of 


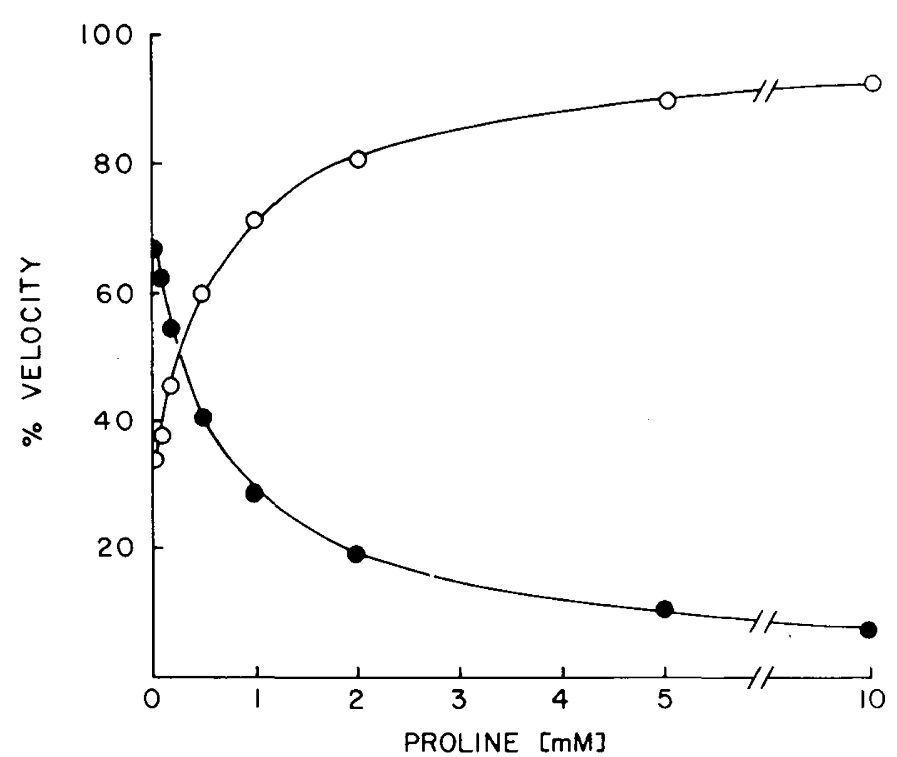

Fig. 5. The \% of the total uptake mediated via the low (-) and high $(\mathrm{O}-\mathrm{O}) \mathrm{Km}$ systems versus the concentration of proline. By using observed kinetic parameters determined from the Hofstee plot as an initial estimate, the kinetic parameters for a two-component system for proline uptake were calculated. The $\%$ contribution of each system was determined from equation (1).

proline is divided into $67 \%$ by the low $\mathrm{Km}$ system and $33 \%$ by the higher $\mathrm{Km}$ system and at $10 \mathrm{mM}$ into $7.2 \%$ by the low $\mathrm{Km}$ system and $92.8 \%$ by the high $\mathrm{Km}$ system. At the physiologic concentration of proline, $0.4 \mathrm{mM}$, (Table 1) both systems appear to be important for proline transport since $44 \%$ of total uptake is via the low $\mathrm{Km}$ system and $56 \%$ is via the higher $\mathrm{Km}$ system.

\section{DISCUSSION}

Our prior data on proline uptake by rat renal cortical slices (24) has now been augmented by our findings with the renal tubule fragment preparation. For the adult kidney there is concentrative and saturable uptake of proline by renal tubule cells despite extensive metabolism of proline. Transport occurs via two distinct systems, one a low $\mathrm{Km}$ high affinity system, the other a high $\mathrm{Km}$ low affinity process. In our hands, both slice and fragment preparations give similar values for these parameters (Table 2) as they have for glycine transport $(15,18)$.

The question has frequently arisen which membrane, the brushborder or the basolateral, mediates the sodium-dependent entry process in the tubule preparation. The ability to separate these membranes and study vesicle uptake of proline has shown that the brushborder membrane vesicles from adult tubules possess the same two systems as the slice and tubule fragments (Table 2). In addition, the low $\mathrm{Km}$ high affinity vesicle system which operates in the physiologic range is sodium-dependent while basolateral membrane vesicles possess sodium-independent uptake of proline. These findings suggest that although the basolateral membrane is exposed to proline during incubation of slices and tubule fragments there is little entry via this site compared to the luminal brushborder membrane. The correspondence of the uptake processes in newborn and adult tissue preparations suggests that parallel systems exist in newborn brushborder membranes.

No data is yet available, however, on the transport systems for proline in isolated brushborder membrane vesicles of newborn rats to correlate with the slice and tubule fragment transport. We have published preliminary data (9) showing a slower but much higher uptake of proline by newborn brushborder membrane vesicles than adult vesicles. Further studies, as yet unpublished, indicate that the reported uptake by newborn vesicles (9) represents extensive binding rather than transport and that the newborn
Table 2. Comparison of $\mathrm{Km}$ for proline uptake by various rat kidney preparations ${ }^{1}$

\begin{tabular}{|c|c|c|c|c|c|}
\hline & \multicolumn{2}{|c|}{ Cortical Slices } & \multicolumn{2}{|c|}{ Tubule Fragments } & \multirow{2}{*}{$\begin{array}{c}\text { Brush- } \\
\text { border } \\
\text { mem- } \\
\text { brane } \\
\text { vesicles }\end{array}$} \\
\hline & Adult & 5 day old & Adult & Newborn & \\
\hline $\mathrm{Km}_{1}$ & 0.53 & 0.40 & 0.17 & 0.17 & 0.07 \\
\hline $\mathrm{Km}_{2}$ & 10.0 & 10.0 & 12.4 & 12.4 & 5.3 \\
\hline
\end{tabular}

${ }^{1} \mathrm{Km}$ is in $\mathrm{mM}$ units. Slice data are from Segal, et al. (24) and were obtained in 30-min incubations. Tubule fragment data are from this paper and are for 3-min incubations. Membrane vesicle data are from McNamara et al. (12) and were obtained in 0.25 -min incubations. All velocity data from which the $\mathrm{Km}$ values were calculated were corrected for diffusion.

membranes used were not comparable in purity to adult membranes.

Adult brushborder membrane vesicle have shown that glycine and proline share transport systems, the low $\mathrm{Km}$ proline mechanism being shared with the high $\mathrm{Km}$ glycine system and the high $\mathrm{Km}$ proline system with the low $\mathrm{Km}$ glycine system. Since it was unequivocally demonstrated that newborn proximal tubule cells possess both high and low $\mathrm{Km}$ systems for glycine it seemed likely that the shared systems for proline should also be demonstrable in the newborn tissue. Our present data show this to be the case for tubule fragments and substantiate our previous observations with cortical slices. Indeed, the $\mathrm{Km}$ and Vmax for both proline systems in the newborn are the same as for the adult (Table 2) and initial uptake rates were also identical. The claim of Baerlocher et al. (3, 4,5 ) of a single proline-glycine transport system in newborn rat kidney was not upheld by our previous work and the present observations now have extended this conclusion to include dual newborn transport systems for proline, as well. The reasons for a lack of discernment of the dual systems by Baerlocher et al. have been discussed in our previous paper (15).

All previous studies of renal proline transport other than those with membrane vesicles (12) have reported extensive metabolism $(4,11,13,14)$. This metabolism does not interfere with an assessment of the parameters of uptake such as the apparent $\mathrm{Km}$. Although the $V \max$ values may alter when incorporation into protein or oxidation is considered in calculation of amounts taken up, the $\mathrm{Km}$ does not change $(4,14)$.

Upon examination of the disposition of radioactive label, we found that both in the TCA soluble and insoluble pools, the label was present in greater absolute amounts in newborn than in adult tissue; thus, the higher measured proline content of newborn cortical slices is reflected faithfully in the higher label accumulation (distribution ratio) and greater label distribution in acid soluble and insoluble fractions in newborn tubules. These findings were paralleled by the observation that $\left[{ }^{14} \mathrm{CO}_{2}\right]$ production, while greater in absolute amount in newborn tubules, was no greater than adult in proportion to the total radioactivity taken up. The major distinction in metabolic disposition of $\left[{ }^{14} \mathrm{C}\right]$-proline appeared to be in its rate of conversion to other metabolites, such as glutamate, which in adult tubules occurred at approximately twice the newborn rate. The above observations of metabolic disposition are at variance with those of Baerlocher, et al. $(3,4)$, who demonstrated a much lower rate of $\left[{ }^{14} \mathrm{CO}_{2}\right]$ evolution in newborn than adult slices; however, we have shown in an earlier report that the Tris-glucose buffer used by these authors has significant adverse effects on transport (15), and conceivably on metabolism, as well. The adverse effects on metabolism could be related to the Trisglucose depression of Vmax, a transport parameter known to be related to intracellular energy metabolism.

If the luminal brushborder transport systems of the newborn renal tubule are not different from those of the adult tubule, how can the hyperaminoaciduria or hyperprolinuria of the newborn 
be explained? The one finding that is not disputed is that newborn tubule cells take up proline, as well as glycine, to a greater extent than the adult at later times of incubation $(15,18,24)$. From a kinetic viewpoint, the increasing distribution ratios we observed in newborn tubules (Fig. 1) results from a much slower efflux of the amino acid from the cells. This has been shown to be the case by direct efflux measurements for glycine (24) and proline (3). If as we postulated (18) the slower efflux component is localized to the basolateral membrane, the newborn tubule may be less able to convey proline from lumen to blood. Such a situation may create backflux across the brushborder into the lumen and slow entry mechanisms thus causing urinary loss. This sequence of events has been postulated to occur in the hyperprolinemic mouse with prolinuria by Scriver et al. (23). The data in Table 1 are compatible with this postulate in that the aminoaciduria of the newborn occurs concomitantly with higher renal cortical levels of proline. The possibility also exists as pointed out by Bergeron et al. (1) that loss of amino acids under some circumstances may occur in the nephron distal to the proximal tubule and result in aminoaciduria. The thought should be entertained that immature distal tubule mechanisms resulting in a leak may be responsible for hyperaminoaciduria and that focusing on the proximal tubule may not yield the explanation of the developmental excretion phenomenon.

\section{REFERENCES AND NOTES}

1. Bergeron, M., Dubord, L., and Hausser, C.: Membrane permeability as a cause of transport defects in experimental Fanconi Syndrome. J. Clin. Invest., 57: 1181 (1976).

2. Blazer-Yost, B., Reynolds, R., and Segal, S.: Amino acid content of rat renal cortex and the response to in vitro incubation. Am. J. Physiol., 5: F398 (1979).

3. Baerlocher, K. E., Scriver, C. R., and Mohyuddin, F.: Ontogeny of iminoglycine transport in mammalian kidney. Proc. Natl. Acad. Sci. USA, 65: 1009 (1970)

4. Baerlocher, K. E., Scriver, C. R., and Mohyuddin, F.: The ontogeny of amino acid transport in rat kidney. I. Effect on distribution ratios and intracellular metabolism of proline and glycine. Biochim. Biophys. Acta, 249: 353 (1971).

5. Baerlocher, K. E., Scriver, C. R., and Mohyuddin, F.: The ontogeny of amino acid transport in rat kidney. II. Kinetics of uptake and effect of anoxia. Biochim. Biophys. Acta, 249: 364 (1971).

6. Brodehl, J.: Postanatal development of tubular amino acid reabsorption. In: Silbernagl, S., Lang, F. and Greger R.: Amino Acid Transport and Uric Acid Transport. p. 128 (Georg Thieme Publishers, Stuttgart, 1976).

7. Burg, M.B. and Orloff, J.: Oxygen consumption and active transport in separated renal tubules. Am. J. Physiol., 203: 327 (1962).

8. DiGiorgio, J.: Nonprotein nitrogenous constituents. In: Henry, R. J. Cannon, D. C. and Winkelman, J. W.: Clinical Chemistry: Principals and Techniques. Chapter 17, p. 541 (Harper and Row, Hagerstown, 2nd edition, 1974).
9. Goldmann, D. A., Roth, K. S., Langfitt, T. W., Jr., and Segal, S.: L-proline transport by newborn rat kidney brush border membranes vesicles. Biochem. J., 178: 253 (1979).

10. Hillman, R. E., Albrecht, I., and Rosenberg, L. E.: Identification and analysis of multiple glycine transport systems in isolated mammalian renal tubules. J. Biol. Chem, 243: 5566 (1968).

11. Holtzapple, P., Genel, M., Rea, C., and Segal, S.: Metabolism and uptake of Lproline by human kidney cortex. Pediatr. Res., 7: 818 (1973)

12. MčNamara, P. D., Ožegovic, B., Pepe, L. M., and Segal, S.: Proline and glycine uptake by renal brushborder membrane vesicies. Proc. Natl. Acad. Sci. USA, 73: 4521 (1976).

13. Mohyuddin, F., and Scriver, C. R.: Similarity of L-proline transport systems in kidney of the rat in vitro and of man in vivo. Biochem. Biophys. Res. Commun., 32: 852 (1968).

14. Mohyuddin, F. and Scriver, C. R.: Amino acid transport in mammalian kidney. Identification and analysis of multiple systems for iminoacid and glycine in rat kidney. Am. J. Physiol., 219: 1 (1970).

15. Reynolds, R., Roth, K. S., Hwang, S. M., and Segal, S.: On the development of glycine transport systems by rat renal cortex. Biochim. Biophys. Acta, 511: 274 (1978).

16. Rosenberg, L. E., Blair, A., and Segal, S.: Transport of amino acids by slices of rat kidney cortex. Biochim. Biophys. Acta, 54: 479 (196I).

17. Rosenberg, L. E., Downing, S. J., and Segal, S.: Extracellular space estimation in rat kidney slices using $\mathrm{C}^{14}$ saccharides and phlorizin. Amer. J. Physiol., 202: 800 (1962).

18. Roth, K. S., Hwang, S. M., London, J. W., and Segal, S.: Ontogeny of glycine transport in isolated rat renal tubules. Am. J. Physiol., 233: F241 (1977).

19. Roth, K. S., Hwang, S. M., and Segal, S.: Effect of maleic acid on the kinetics of $\alpha$-methyl-D-glucoside uptake by isolated renal tubules. Biochim. Biophys. Acta, 426: 675 (1976).

20. Roth, K. S., Hwang, S. M., Yudkoff, M., and Segal, S.: On the transport of sugars and amino acids by newborn kidney: Use of isolated proximal tubules. Life Sci. 18: 1125 (1976).

21. Scharff, R. and Wool, I. G.: Effect of diabetes on concentration of amino acids in plasma and heart muscle of rats. Biochem. J., 99: 173 (1966).

22. Scriver, C. R. and Mohyuddin, F.: Amino acid transport in kidney: heterogeneity of $\alpha$-aminoisobutyric acid uptake. J. Biol. Chem., 243: 3207 (1968).

23. Scriver, C. R., McInnes, R. R., and Mohyuddin, F.: Role of epithelial architecture and intracellular metabolism in proline uptake and transtubular reclamation in PRO/Re mouse kidney. Proc. Natl. Acad. Sci. USA, 72: 1431 (1975).

24. Segal, S., Rea, C., and Smith, I,: Separate transport systems for sugars and amino acids in developing rat kidney cortex. Proc. Natl. Acad. Sci. USA, 68: 372 (1971).

25. Webber, W. A. Amino acid excretion patterns in developing rats. Can. J. Physiol. Pharmacol., 45: 867 (1967).

26. Requests for reprints should be addressed to: Dr. Stanton Segal, Division of Biochemical Development and Molecular Diseases, Children's Hospital of Philadelphia, 34th Street and Civic Center Boulevard, Philadelphia, PA 19104.

27. This research was supported by Grants AM 10894 and HD 08536 from the National Institutes of Health. Dr. Roth is a recipient of a Career Development Award K04 HD00257.

28. Received for publication January 20, 1982.

29. Accepted for publication April 22, 1982. 